\title{
Efektivitas Pembelajaran Matematika Melalui Pendekatan PMRI Terhadap Kompetensi Pengetahuan Matematika
}

\author{
Ni Putu Wulan Pratami Dewi ${ }^{*}$, Gusti Ngurah Sastra Agustika² \\ 12 Prodi Pendidikan Guru Sekolah Dasar, Universitas Pendidikan Ganesha
}

\begin{abstract}
Abstrak
Salah satu penyebab rendahnya kompetensi pengetahuan matematika yang dialami siswa kelas IV adalah kurangnya minat peserta didik pada mata pelajaran matematika yang sulit untuk dipahami. Penelitian ini bertujuan untuk menganalisis efektivitas pembelajaran matematika melalui pendekatan PMRI terhadap kompetensi pengetahuan matematika kelas IV. Penelitian ini merupakan kuasi eksperimen dengan rancangan kelompok non-ekuivalen. Populasi penelitian yaitu seluruh kelas IV sebanyak 593 siswa. Pengambilan sampel pada penelitian ini menggunakan teknik cluster random sampling. Tes yang dipilih sebagai instrument berupa test dengan pilihan ganda biasa. Data post-test yang didapat kemudian dianalisis dengan uji-t menggunakan rumus polled varians. Berdasarkan taraf signifikansi $5 \%$ dan $\mathrm{dk}=82$ diperoleh $t_{\text {hitung }}=2,217>t_{\text {tabel }}=1,989$. Hal ini membuktikan terdapat perbedaan signifikan kompetensi pengetahuan matematika antara kelompok eksperimen sebagai kelompok yang diajarkan menggunakan pendekatan PMRI dan kelompok kontrol sebagai kelompok yang diajarkan menggunakan pembelajaran konvensional. Penerapan pendekatan PMRI dapat membuat peserta didik lebih termotivasi dalam belajar dan mereka dapat memahami suatu konsep matematika melalui media konkret tanpa harus berpikir abstrak
\end{abstract}

\begin{abstract}
One of the reasons for the low mathematical knowledge competency experienced by fourth-grade students is the lack of students' interest in mathematics which is difficult to understand.. This study aims to determine the effectiveness of learning mathematics through the PMRI approach to the mathematical knowledge competency of fourth-grade students. This research was a quasi-experimental design with a non-equivalent group. The research population was all of fourth-grade students as much as 593 students. The sampling technique used for this research was cluster random sampling. The test chosen as an instrument was a multiple-choice test. The obtained post-test data were analyzed by t-test using the pooled variance formula. Based on the significance level of $5 \%$ and $\mathrm{dk}=82$ obtained tcount $=2.217>$ ttable $=1.989$. The result revealed that there was a significant difference in the mathematical knowledge competency between the experimental groups as the groups that were taught using the PMRI approach and the control groups as the groups that were taught using conventional learning. The implementation of the PMRI approach can make students more motivated in learning and they can understand a mathematical concept through concrete media without having to think abstractly.
\end{abstract}

\section{Keywords:}

PMRI approach, mathematical knowledge competence, effectiveness

\footnotetext{
* Corresponding author.

E-mail Addresses: - putuwulantami164@gmail.com (Ni Putu Wulan Pratami Dewi)
} 


\section{PENDAHULUAN}

Pembelajaran matematika adalah suatu proses interaksi antara guru dengan siswa dalam suatu bentuk aktivitas yang terorganisir untuk memperoleh, memahami, serta mampu mengomunikasikan informasi yang telah diperoleh sebelumnya (Arianti, 2019). Menurut Advina Ria Christianti (2018) dalam pembelajaran matematika siswa tidak hanya harus menghafal rumus-rumus saja, begitupula guru sebiknya tidak menyajikan konsep secara langsung dalam bentuk jadi (final) tetapi siswa diharapkan menemukan sendiri konsep pengetahuannya. Darmayanti (2016) menyatakan matematika merupakan salah satu disiplin ilmu yang dapat meningkatkan kemampuan berpikir dan beragumentasi, memberikan kontribusi dalam penyelesaian masalah sehari-hari dan dalam dunia kerja, serta memberikan dukungan dalam pengembangan ilmu pengetahuan dan teknologi. Matematika mempunyai peranan penting untuk meningkatkan kemampuan berpikir, berpendapat dan juga dapat berpartisipasi aktif dalam menyelesaikan masalah yang ditemukan. Kusmanto \& Marliyana (2014) menyatakan bahwa matematika telah banyak memberikan sumbangan dalam perkembangan ilmu pengetahuan maupun teknologi. Oleh sebab itu, maka pembelajaran matematika sangat penting dilakukan. Senada dengan itu, Deviana Novita (2017) menyebutkan bahwa tujuan pembelajaran matematika di sekolah dasar adalah agar peserta didik memiliki kemampuan: (1) memahami konsep matematika, mengetahui keterkaitan antar konsep dan mampu mengaplikasikan konsep atau algoritma matematika itu secara luwes, akurat, efisien, dan tepat dalam pemecahan masalah. (2) menggunakan penalaran pada pola dan sifat, melakukan manipulasi matematika dalam membuat generalisasi, menyusun bukti atau menjelaskan gagasan dan pernyataanpernyataan matematika. (3) memecahkan masalah yang meliputi kemampuan memahami masalah, merancang model matematika, menyelesaikan model dan menafsirkan/menginterpretasikan solusi yang diperoleh. (4) mengomunikasikan gagasan dengan simbol, tabel, diagram, atau media lain untuk memperjelas keadaan atau masalah. (5) memiliki sikap menghargai kegunaan matematika dalam kehidupan yaitu memiliki rasa ingin tahu, perhatian dan minat dalam mempelajari matematika serta sikap ulet dan percaya diri dalam pemecahan masalah.

Namun, pada kenyataannya matematika dianggap sebagai mata pelajaran yang sulit dan membosankan sehingga belum mampu menarik minat siswa untuk menyukai mata pelajaran matematika. Mayoritas siswa tidak menyukai pelajaran matematika, apabila guru menanyakan kepada siswa mengenai pelajaran yang kurang diminati maka sebagian besar siswa akan menjawab matematika (Hadi, 2018). Matematika secara turun temurun dianggap sebagai mata pelajaran yang sukar dan kurang diminati oleh siswa sehingga menyebabkan rendahnya kompetensi pengetahuan siswa pada mata pelajaran matematika (D. Novitasari, 2016). Berdasarkan peringkat capaian indeks PISA pada tahun 2000 peringkat Indonesia pada bidang membaca, matematika, dan sains berturut-turut berada di posisi 39, 39 dan 38 dari 41 negara. Hingga tahun 2015, Indonesia tidak mengalami peningkatan peringkat secara signifikan, bahkan hanya mampu berada pada peringkat 61, 63 dan 62 dari 69 negara. Berikut rincian pencapaian Indonesia dalam PISA, khususnya matematika.

Tabel 1. Capain Indeks PISA Indonesia Tahun 2000-2015

\begin{tabular}{llcccc}
\hline Tahun & $\begin{array}{l}\text { Materi yang } \\
\text { Disajikan }\end{array}$ & $\begin{array}{l}\text { Skor } \\
\text { Rata } \\
\text { Indonesia }\end{array}$ & $\begin{array}{l}\text { Rata- } \\
\text { Skor } \\
\text { Rata } \\
\text { Internasional }\end{array}$ & $\begin{array}{l}\text { Rata- } \\
\text { Indonesia }\end{array}$ & $\begin{array}{l}\text { Jumlah } \\
\text { Negara } \\
\text { Partisipan }\end{array}$ \\
\hline 2000 & Membaca & 371 & 500 & 39 & 41 \\
& Matematika & 367 & 500 & 39 & \\
& Sains & 393 & 500 & 38 & 40 \\
2003 & Membaca & 382 & 500 & 39 & \\
& Matematika & 360 & 500 & 38 & \\
& Sains & 395 & 500 & 38 & \\
2006 & Membaca & 393 & 500 & 48 & \\
& Matematika & 396 & 500 & 50 & \\
& Sains & 393 & 500 & 50 & \\
& Membaca & 402 & 500 & 57 & \\
& Matematika & 371 & 500 & 61 & \\
& Sains & 383 & 500 & 60 & \\
\hline \multirow{2}{*}{2015} & Membaca & 396 & 500 & 62 & \\
\hline
\end{tabular}




$\begin{array}{llll}\text { Matematika } & 386 & 500 & 63 \\ \text { Sains } & 403 & 500 & 62\end{array}$

Rendahnya capaian indeks PISA Indonesia disebabkan oleh berbagai aspek pembelajaran, salah satunya adalah proses belajar-mengajar itu sendiri. Penerapan metode pembelajaran ceramah atau Direct Instruction (DI) pada mata pelajaran matematika menyebabkan rendahnya aktivitas yang membangun struktur kognitif siswa. Variasi metode dan pendekatan pembelajaran sangat diperlukan guna mengubah paradigma pembelajaran matematika yang abstrak dan sulit menjadi nyata dan menyenangkan. Selain rendahnya indeks pembelajaran matematika oleh PISA, terdapat fakta di lapangan bahwa belum optimalnya kompetensi pengetahuan matematika siswa. Hal ini dibuktikan dengan rendahnya tingkat ketercapaian KKM siswa kelas IV SD Gugus Kompyang Sujana, Kecamatan Denpasar Barat Tahun Ajaran 2019/2020. Berdasarkan data PTS matematika siswa kelas IV SD Gugus Kompyang Sujana sebanyak 62,56\% siswa belum mencapai KKM dan hanya 32,43\% yang telah mencapai KKM dari total 593 siswa. Rendahnya kompetensi pengetahuan matematika siswa disebabkan oleh sulitnya proses asosiasi pembelajaran matematika oleh siswa. Hal ini terjadi karena adanya kesenjangan tingkat perkembangan kognitif siswa dengan pembelajaran matematika yang bersifat abstrak dan seringkali disampaikan dengan metode dan pendekatan yang kurang tepat.

Menurut teori perkembangan kognitif Piaget, peserta didik pada jenjang usia 9 sampai 10 tahun berada pada tahap operasional konkret (Santrock, 2008). Pada tahap operasional konkret, siswa berpikir secara konkret atau nyata sehingga siswa pada tahap ini sering kali mengalami kesulitan dalam menangkap pembelajaran matematika yang bersifat abstrak. Oleh karena itu, pembelajaran matematika pada siswa yang berada di tahap operasional konkret perlu disesuaikan sedemikian rupa agar dapat mempermudah pemahaman siswa mengenai konsep matematika yang sifatnya abstrak. Pembelajaran yang dimaksud harus dapat mentransformasikan matematika yang bersifat abstrak menjadi matematika realistik sehingga lebih mudah diterima siswa. Pembelajaran tersebut yaitu pembelajaran yang dapat menggiring siswa pada aktivitas manusia dan dihubungkan secara nyata terhadap konteks kehidupan sehari-hari siswa ke pengalaman belajar yang berorientasi pada hal-hal real atau nyata (Ibda, 2015).

Pada proses pembelajaran diperlukan adanya suatu metode pembelajaran. Metode pembelajaran mengacu pada pendekatan pembelajaran yang akan digunakan, termasuk di dalamnya tujuan-tujuan pembelajaran, tahap-tahap dalam kegiatan pembelajaran, lingkungan pembelajaran, dan pengelolaan kelas. Pendekatan pembelajaran harus disesuaikan dengan berbagai macam aspek seperti karakter materi pembelajaran, karakter siswa, sarana dan prasarana, serta aspek pendukung lainnya. Metode dan pendekatan pembelajaran yang tepat akan memudahkan siswa dalam mengasosiasi pembelajaran yang telah dilakukan. Sebaliknya, metode pembelajaran tidak sesuai dengan aspek belajar-mengajar akan menyebabkan siswa mengalami kesulitan dalam menerima informasi dan mengasosiasi ke dalam struktur kognitifnya.

Pembelajaran matematika dengan metode ceramah pada siswa yang berada di tahap operasional konkret menyebabkan siswa mengalami kesulitan dalam mengasosiasi informasi dalam membangun struktur kognitifnya. Metode dan pendekatan pembelajaran yang sering digunakan selama ini belum mampu mengubah cara pandang siswa mengenai matematika yang abstrak menjadi nyata menyebabkan siswa mengalami kesulitan dalam belajar matematika dan cenderung tidak menyukai matematika. Permasalahan ini menyebabkan rendahnya kompetensi pengetahuan matematika siswa. Pendekatan pembelajaran bagi siswa yang berada di tahap operasional konkret harus dapat mengubah cara pandang siswa terhadap matematika yang abstrak menjadi nyata. Pendekatan pembelajaran yang dimaksud hendaknya bersifat kontekstual yaitu dengan memberikan peserta didik contoh berdasarkan aktivitas yang dilakukan oleh siswa. Konsep yang dapat digunakan guru di sekolah yaitu dengan menggunakan pendekatan PMRI (Pendidikan Matematika Realistik Indonesia).

Pendekatan PMRI merupakan suatu pendekatan pembelajaran matematika yang menekankan pada aktivitas siswa dan berpijak dari hal yang riil (kontekstual) bagi siswa. Pada pendekatan matematika realistik, siswa dipandang sebagai individu (subjek) yang memiliki pengetahuan dan pengalaman sebagai hasil interaksinya dengan lingkungan. Melalui eksplorasi berbagai masalah, baik masalah kehidupan sehari-hari maupun masalah matematika, siswa dapat merekonstruksi kembali temuan-temuan dalam bidang matematika (Munir \& Shoelahah, 2020). Selain itu, pendekatan PMRI merupakan suatu pendekatan yang memanfaatkan kehidupan sehari-hari dimana pendekatan ini menempatkan penekanan penggunaan suatu situasi yang bisa dibayangkan (imanginable) oleh siswa (Prihartini, 2020). Prinsip emergent modeling dalam PMR menuntut ketersediaan media pembelajaran agar siswa dapat membayangkan situasi masalah yang diberikan (Lus,2020). Pendekatan PMRI merupakan salah satu 
alternatif pendekatan pembelajaran yang memberikan kesempatan kepada siswa untuk belajar matematika secara bermakna dan realistik.

Pendekatan PMRI merupakan konsep yang cocok diterapkan oleh guru di sekolah dasar. Hal ini karena PMRI merupakan konsep matematika yang dapat mengaitkan aktivitas yang dilakukan oleh siswa dengan pembelajaran matematika sehingga konsep matematika tampak nyata atau riil dan dapat diterima oleh siswa. Penerapan konsep ini dapat membantu siswa dalam memahami pembelajaran yang disampaikan oleh guru terutama dalam pembelajaran matematika. Lewat pendekatan PMRI peserta didik dapat menerima konsep yang telah diberikan oleh guru dan mengembangkan kembali konsep tersebut sesuai pemahaman yang dimiliki oleh peserta didik sehingga kegiatan pembelajaran menjadi bermakna (Putri, 2011).

Pembelajaran di sekolah dasar harus dapat menciptakan perubahan pada diri siswa, baik menyangkut aspek kognitif, afektif maupun psikomotor. Perubahan pada aspek kognitif dalam Kurikulum 2013 menyangkut perubahan pada kompetensi pengetahuan siswa. Pembelajaran yang kondusif dan inovatif akan mempengaruhi kompetensi pengetahuan siswa, oleh karena itu diperlukan peranan guru yang dapat menunjang kegiatan proses pembelajaran agar siswa dapat memahami materi pembelajaran. Pembelajaran matematika dengan menggunakan pendekatan PMRI menyediakan masalah nyata yang biasa ditemui oleh siswa dan diharapkan pada saat mengerjakan soal cerita siswa mampu untuk menyelesaikannya (Idris \& Silalahi, 2016). PMRI merupakan aktivitas belajar yang mengaitkan pembelajaran matematika dengan kehidupan nyata siswa dalam kegiatan sehari-hari (Widyastuti \& Pujiastuti, 2014). Treffers (dalam Putri, 2011) memaparkan karakteristik PMRI, diantaranya: 1) menggunakan masalah kontekstual (phenomenological exploration or the use of contexts), 2) menggunakan model (the use of models or bridging by vertical instruments), 3) menghargai ragam jawaban dan kontribusi siswa (the use of students own), 4) interaktivitas (the interactive character of the teaching process or interactivity) dan 5) terintegrasi dengan topik pembelajaran lainnya (the intertwining of various learning strands). Karakteristik dari pendekatan PMRI berkaitan dengan materi pembelajaran (karakteristik 1, 2, dan 5), metode (karakteristik 4), dan assesment (karakteristik 3).

Penerapan pendekatan PMRI dipandang mampu meningkatkan kompetensi pengetahuan matematika siswa. Hal ini didukung oleh beberapa penelitian relevan sebelumnya yaitu oleh Nugraheni \& Sugiman, 2013, dalam penelitiannya menunjukkan bahwa pendekatan PMRI berpengaruh terhadap aktivitas dan pemahaman konsep matematika serta pendekatan PMRI lebih baik dibandingkan DI ditinjau dari aktivitas dan pemahaman konsep matematika siswa kelas VII SMP Negeri 4 Banguntapan Bantul. Hal senada juga diungkapkan Widyastuti dan Pujiastuti. Hasil penelitian Widyastuti \& Pujiastuti (2014) menunjukkan terdapat pengaruh yang signifikan antara pembelajaran matematika dengan PMRI dan DI pada materi jarak dan kecepatan terhadap pemahaman konsep dan berpikir logis siswa kelas V Sekolah Dasar segugus II Kecamatan Umbulharjo Kota Yogyakarta. Menurut L.Novitasari \& Leonard (2017) pemahaman konsep matematika memiliki pengaruh yang signifikan terhadap hasil belajar matematika.

Kemampuan literasi juga memiliki peranan penting dalam meningkatkan hasil belajar. Menurut Setyaningsih (2017), pendekatan PMRI dengan alat peraga mampu meningkatkan kemampuan literasi siswa. Selain itu, Faot \& Amin (2020) juga menyebutkan pendekatan PMRI berpengaruh signifikan terhadap hasil belajar matematika siswa. Penelitian ini menunjukkan bahwa kelas dengan pendekatan PMRI memiliki hasil belajar matematika yang lebih tinggi daripada kelas kontrol. Wibowo (2017) juga menyebutkan bahwa pendekatan PMRI lebih berpengaruh efektif dibandingkan pendekatan saintifik dan konvensional terhadap prestasi belajar, kemampuan penalaran matematis, dan minat belajar. Senada dengan itu, Wahidin \& Sugiman (2014) mengungkapkan bahwa pendekatan PMRI memberikan pengaruh yang lebih baik dalam meningkatkan motivasi berprestasi, kemampuan pemecahan masalah, dan prestasi belajar. Widodo (2014) menyatakan bahwa pendekatan PMRI efektif ditinjau dari hasil belajar matematika siswa pada materi lingkaran. Yulia \& Jamaliah (2016) juga menyebutkan bahwa pembelajaran matematika dengan pendekatan PMRI mampu meningkatkan hasil belajar matematika siswa. Pendekatan PMRI lebih efektif dalam meningkatkan hasil belajar matematika siswa daripada pendekatan Kurikulum 2013. (Saleh et al., 2018) juga menyebutkan prestasi dan peningkatan kemampuan penalaran matematis siswa yang diajarkan dengan pendekatan PMRI lebih baik daripada kemampuan penalaran matematis siswa yang diajarkan dengan menggunakan pembelajaran konvensional. Berkaitan dengan itu, (Setiawan, 2016) menyebutkan bahwa siswa dengan kemampuan penalaran matematis tinggi memiliki prestasi belajar matematika lebih baik daripada siswa dengan kemampuan penalaran matematis sedang dan rendah. Kemampuan penalaran matematis berbanding lurus dengan prestasi atau kompetensi pengetahuan matematika siswa. Hasil penelitian ini sejalan dengan penelitian Oftiana \& Saefudin (2017) yang menunjukkan bahwa pendekatan Pembelajaran Matematika Realistik Indonesia (PMRI) berpengaruh terhadap kemampuan pemecahan masalah matematika siswa. Novita (2015) menyebutkan 
adanya korelasi yang tinggi antara kemampuan pemecahan masalah dengan prestasi belajar. Siswa dengan kemampuan pemecahan masalah yang tinggi memiliki prestasi belajar yang tinggi pula.

Penerapan pendekatan PMRI merupakan konsep matematika yang dapat menggambarkan permasalahan yang ditemukan oleh siswa dalam kegiatan belajar mengajar di sekolah sehingga siswa dapat menemukan cara dalam menyelesaikan permasalahan yang telah ditemukan (Yulia \& Jamaliah, 2016). Partisipasi aktif dari guru dan peserta didik selama kegiatan pembelajaran sangat perlu agar pendekatan PMRI dapat terlaksana dengan baik dan memperoleh hasil yang optimal. Oleh karena itu untuk mengetahui efektivitas pembelajaran matematika, guru dapat menerapkan pendekatan PMRI dalam kegiatan pembelajaran. Selain itu dapat digunakan untuk mengetahui perbedaan kompetensi pengetahuan matematika, saat diterapkannya metode konvensional dan pendekatan PMRI. Tujuan dan fokus penelitian ini untuk menganalisis perbedaan dan efektivitas pembelajaran matematika melalui pendekatan PMRI terhadap kompetensi pengetahuan matematika siswa kelas IV Gugus Kompyang Sujana Kecamatan Denpasar Barat Tahun Ajaran 2019/2020.

\section{METODE PENELITIAN}

Jenis Penelitian yang dilakukan menggunakan rancangan eksperimen kuasi. Pada design ini, sebelum dilakukan penelitian untuk mengetahui keadaan awal kedua kelompok diberi pre-test (0). Kemudian kelompok pertama diberi perlakuan (X) dan kelompok lain tidak mendapatkan perlakuan. Kelompok mendapatkan perlakuan dijadikan kelompok eksperimen dan kelompok yang tidak mendapatkan perlakuan dijadikan kelompok kontrol, selanjutnya di akhir penelitian, kedua kelas diberi post-test (0) untuk melihat hasilnya. Bentuk rancangan yang digunakan adalah Non-Ekuivalen.

Populasi penelitian ini adalah seluruh kelas IV SD Gugus Kompyang Sujana, Kecamatan Denpasar Barat tahun ajaran 2019/2020 yang terdiri dari tujuh Sekolah Dasar dengan jumlah siswa 593. Sampel dalam penelitian ini diambil dengan cara teknik cluster random sampling. Random dilakukan terhadap sejumlah kelas sebagai kelompok dan bukan pengacakan terhadap individu melainkan pengacakan kelas. Kelas sebagaimana telah terbentuk tanpa campur tangan peneliti. Penentuan sampel penelitian dilakukan dengan cara pengundian. Pertama-tama, seluruh kelompok kelas atau anggota populasi ditulis namanya pada kertas kecil yang berukuran sekitar $5 \times 5 \mathrm{~cm}$. Kemudian kertas digulung dan dimasukkan ke dalam satu wadah (kotak). Lakukan pengundian untuk mendapatkan dua kelas, dari hasil pengundian tersebut diperoleh dua kelas yang dijadikan sampel penelitian. Setelah dilakukan pengundian diperoleh hasil kelas IV B SD Negeri 1 Padang Sambian dan Kelas IV A SD Negeri 2 Padang Sambian. Kedua kelas ini diuji kesetaraannya dengan menggunakan hasil pre-test. Pemberian pre-test untuk mengukur kemampuan awal siswa. Sebelum dilakukan uji kesetaraan dilakukan uji prasyarat analisis yaitu uji normalitas dengan menggunakan Kolmogorov Smirnov, dan uji homogenitas varians dengan menggunakan uji Fisher. Setelah uji prasyarat analisis dilakukan uji kesetaraan dengan menggunakan uji t.

Berdasarkan hasil uji-t didapat bahwa kedua kelompok sampel dinyatakan setara dengan analisis $t_{\text {hitung }}=1,116$ dan $t_{\text {tabel }}=1,989$ pada taraf signifikansi $5 \%(0,05)$ dengan derajat kebebasan $\mathrm{dk}=(45+39-2)$ = 82. Berdasarkan uji kesetaraan yang dilakukan terdapat bahwa $t_{\text {hitung }}=1,116<t_{\text {tabel }}=1,989$ maka $H_{0}$ diterima sehingga dua kelompok sampel dinyatakan setara. Setelah diketahui kedua kelompok setara maka dilakukan pengundian kembali untuk menentukan kelas eksperimen dan kelas kontrol. Berdasarkan hasil pengundian, diperoleh kelas IV B SD Negeri 1 Padang Sambian sebagai kelas eksperimen yang diberikan perlakukan pendekatan PMRI dan kelas IV A SD Negeri 2 Padang Sambian sebagai kelas kontrol yang melaksanakan pembelajaran konvensional.

Penelitian ini dikatakan valid apabila hasil yang diperoleh disebabkan oleh variabel bebas yang dimanipulasi dan hasilnya dapat diberlakukan pada populasi penelitian. Oleh karena itu, untuk menyakinkan bahwa hasil eksperimen benar-benar sebagai akibat pemberian perlakuan, dilakukan pengontrolan validitas internal dan validitas eksternal. Data yang dikumpulkan dalam penelitian ini ialah data post test kompetensi pengetahuan matematika. Pada proses mengumpulkan data, metode yang diterapkan ialah metode tes. Tes yang digunakan dalam penelitian ini berupa tes obejktif bentuk pilihan ganda biasa dengan jumlah soal sebanyak 40 butir soal. Penyusunan soal tersebut mengacu pada KD dan Indikator. KD yang digunakan diantaranya: 1) Menganalisis sifat-sifat segi banyak beraturan dan segi banyak tidak beraturan, 2) Menjelaskan dan menentukan keliling dan luas persegi, persegi panjang dan segitiga. Indikator yang diukur hanya terbatas apadapun C1-C4 adapun yang digunakan yaitu : 1) Mampu menyebutkan jenis segi banyak beraturan dan tidak beraturan 2) Mampu menghitung luas dan keliling persegi, persegi panjang, dan segiriga, 3) Menganalisis permasalahan sehari-hari tentang luas dan keliling persegi, persegi panjang dan segitiga. Setelah uji coba dianalisis validitas butir, daya pembeda, tingkat kesukaran dan reliabitas. Banyak butir tes yang memenuhi syarat pada uji coba tersebut sebanyak 30 butir tes. Butir tes tersebut kemudian diujicobakan kepada kelompok eksperimen dan kelompok kontrol 
untuk memperoleh data nilai posttest. Hasil data tersebut dianalisis menggunakan Uji-t polled varians dengan taraf signifikan $5 \%(0,05)$ guna memperoleh data perbedaan antara kelompok eksperimen dengan kelompok kontrol. Sedangkan untuk memperoleh hasil data efektivitas digunakan analisis data koefisien chohen d.

\section{ANALISIS DAN PEMBAHASAN}

Penelitian Setelah diberikan perlakuan (treatment) menggunakan pendekatan PMRI sebanyak 6 kali pada kelompok eksperimen, di akhir eksperimen siswa diberikan post test untuk memperoleh data kompetensi pengetahuan matematika siswa. Data kompetensi pengetahuan matematika siswa kelas IV SD Negeri Gugus Kompyang Sujana Kecamatan Dennpasar Barat Tahun Ajarran 2019/2020 yang dijadikan sampel penelitian sebanyak 84 siswa. Deskripsi data sampel penelitian disajikan dalam tabel deskripsi data dan grafik steam and leave dapat dilihat pada tabel 2.

Tabel 2. Ringkasan Data Post-Test Kompetensi Pengetahuan MatematikaKelompok Eksperimen dan Kelompok Kontrol

\begin{tabular}{lcc}
\hline \multicolumn{1}{c}{ Hasil Analisis } & Kelompok Eksperimen & Kelompok Kontrol \\
\hline Rata-Rata & 77,133 & 72,487 \\
Variansi & 85,936 & 98,572 \\
Standar Deviasi & 9,270 & 9,928 \\
Nilai Maksimum & 96 & 93 \\
Nilai Minimum & 60 & 56 \\
\hline
\end{tabular}

Berdasarkan Tabel 2. kompetensi pengetahuan matematika siswa kelas IV pada sekolah sampel terdapat perbedaan yang signifikan. Hal ini terlihat dari rata-rata kelompok eksperimen sebanyak 77,133 sedangkan rata-rata kelompok kontrol sebanyak 72,487, variansi kelompok eksperimen sebanyak 85,936 sedangkan variansi kelompok control sebanyak 98,572, standar deviasi kelompok eksperimen sebanyak 9,270 sedangkan standar deviasi kelompok control sebanyak 9,928, nilai maksimum kelompok eksperimen sebanyak 96 sedangkan nilai maksimum kelompok control sebanyak 93 dan nilai minimum kelompok eksperimen sebanyak 60 sedangkan nilai minimum kelompok control sebanyak 56.

Uji prasyarat dilakukan terlebih dahulu sebelum uji hipotesis menggunakan uji-t. Uji prasyarat tersebut meliputi uji normalitas dan uji homogenitas varians. Berdasarkan hasil uji normalitas kelompok eksperimen diperoleh nilai max $|\mathrm{Ft}-\mathrm{Fs}|=0,081$ kemudian nilai tersebut dibandingkan dengan nilai tabel Kolmogorov (nilai tabel Kolmogorov = 0,202). Hal ini menunjukkan bahwa nilai maksimum $\mid$ FT - FS $\mid<$ nilai tabel Kolmogorov-Smirnov berarti data hasil kompetensi pengetahuan matematika kelompok eksperimen berdistribusi normal. Berdasarkan hasil uji normalitas kelompok kontrol diperoleh nilai max $\mid$ Ft-Fs $\mid=0,102$ kemudian nilai tersebut dibandingkan dengan nilai table Kolmogorov (nilai table Kolmogorov $=0$,217). Hal ini menunjukkan bahwa nilai maksimum $\mid$ FT - FS $\mid<$ nilai tabel KolmogorovSmirnov berarti data hasil kompetensi pengetahuan matematika kelompok eksperimen berdistribusi normal.

Pengujian homogenitas varians antar kelompok dilalukan untuk meyakinkan bahwa perbedaan yang diperoleh uji-t benar-benar berasal dari perbedaan antara kelompok bukan disebabkan oleh perbedaan di dalam kelompok. Uji homogenitas varians dilakukan dalam penelitian ini menggunakan uji F. Dari hasil analisis diperoleh $F_{\text {hitung }}=1,147$ dan $F_{\text {tabel }}=1,674$. Hal ini berarti $F_{\text {hitung }}<F_{\text {tabel }}$ sehingga data kedua kelompok memiliki varians yang homogen. Berdasarkan hasil uji prasyarat yang terdiri dari uji normalitas dan uji homogenitas varians dapat disimpulkan bahwa kedua kelompok sampel ialah berdistribusi normal dan memiliki varians yang homo-gen. Oleh karena itu, uji hipotesis dilakukan dengan uji-t. Hipotesis penelitian yang diuji dalam penelitian ini adalah hipotesis nol $\left(\mathrm{H}_{0}\right)$ yang berbunyi tidak terdapat perbedaan yang signifikan kompetensi pengetahuan matematika kelompok siswa yang dibelajarkan menggunakan pendekatan PMRI dengan kelompok yang dibelajarkan menggunakan pembelajaran konvensional pada siswa kelas IV SD Gugus Kompyang Sujana Tahun Ajaran 2019/ 2020. Berdasarkan hasil uji normalitas sebaran data dan uji homogenitas varians dapat diketahui bahwa data yang diperoleh dari kelompok eksperimen dan kelompok kontrol berdistribusi normal dan memiliki varians yang homogen. Karena data yang diperoleh telah memenuhi uji prasyarat, maka uji hipotesis dapat dilakukan dengan menggunakan uji-t. Berikut disajikan rekapitulasi hasil analisis data dengan menggunakan uji-t pada Tabel 3. 
Tabel 3. Rekapitulasi Hasil Uji-t

\begin{tabular}{llccccccc}
\hline No. & Kelompok & Rerata & $\mathbf{S}^{\mathbf{2}}$ & $\mathbf{N}$ & $\mathbf{D k}$ & $\mathbf{t}_{\text {hitung }}$ & ttabel & Simpulan \\
\hline 1. & Eksperimen & 77,133 & 85,936 & 45 & 82 & 2,217 & \multirow{2}{*}{1,989} & $\mathrm{H}_{0}$ ditolak \\
2. & Kontrol & 72,487 & 98,572 & 39 & 82 & \\
\hline
\end{tabular}

Dari hasil analisis diperoleh $t_{\text {hitung }}=2,217$ dan $t_{\text {tabel }}=1,989$ pada taraf signifikansi $5 \%$ dengan dk= 82. Oleh karena $t_{\text {hitung }}>t_{\text {tabel }}$ maka $H_{0}$ yang menyatakan tidak terdapat perbedaan yang signifikan kompetensi pengetahuan matematika kelompok siswa yang dibelajarkan menggunakan pendekatan PMRI dengan kelompok siswa yang dibelajarkan menggunakan pembelajaran konvensional pada kelas IV SD Gugus Kompyang Sujana ditolak, dan berarti Ha menyatakan terdapat perbedaan yang signifikan pada kompetensi pengetahuan matematika kelompok yang dibelajarkan menggunakan pendekatan PMRI dengan kelompok yang dibelajarkan menggunakan pembelajaran konvensional pada siswa kelas IV SD Gugus Kompyang Sujana diterima.

Setelah dilakukan pengujian hipotesis, langkah selanjutnya adalah mencari besarnya efek untuk melihat efektivitas pendekatan sehingga menyebabkan perbedaan yang signifikan. Efektivitas dibutuhkan karena signifikasi statistik tidak memberikan informasi yang cukup berarti terkait dengan besarnya perbedaan kompetensi pengetahuan matematika yang terjadi pada kelompok sampel. Jadi dari itu efektivitas penting untuk mengetahui besar perbedaan yang terdapat pada kelompok yang diberikan perlakukan. Perhitungan efektivitas dilakukan dengan menentukan Koefisien Cohen's d. Berdasarkan hasil perhitungan efektivitas, besarnya efektivitas penerapan pendekatan PMRI terhadap kompetensi pengetahuan matematika siswa dapat direkapitulasi pada Tabel 4 berikut.

Tabel 4. Rekapitulasi Hasil Perhitungan Efektivitas Pendekatan PMRI

\begin{tabular}{lcccccc}
\hline Kelompok Sampel & $\begin{array}{c}\text { Nilai rata- } \\
\text { rata post- } \\
\text { test }\end{array}$ & $\mathrm{N}$ & Variansi & Nilai Sp & Nilai d & Kriteria \\
\hline Eksperimen & 77,133 & 45 & 85,936 & 9,580 & 0,484 & Efek Sedang \\
Kontrol & 72,487 & 39 & 98,572 & 9872 \\
\hline
\end{tabular}

Berdasarkan tabel 4 diketahui nilai Koefisien Cohen's d = 0,484. Sesuai dengan kriteria efektivitas menurut Cohen, nilai d sebesar 0,484 termasuk dalam kategori efek sedang. Sehingga, dapat dinyatakan bahwa pendekatan PMRI yang diterapkan pada kelompok eksperimen memberikan efek dengan kategori sedang terhadap kompetensi pengetahuan matematika siswa.

Diterapkannya pendekatan PMRI dalam pembelajaran matematika berpengaruh positif terhadap kompetensi pengetahuan matematika siswa. Selama proses pembelajaran berlangsung siswa terlihat aktif saat mengikuti pembelajaran, pembelajaran menjadi lebih menyenangkan, siswa belajar memecahkan masalah yang diberikan oleh guru, memikirkan berbagai kemungkinan jawaban melalui proses diskusi kelompok. Hal ini dapat dilihat dari hasil perhitungan diketahui bahwa hasil analisis uji t diperoleh $t_{\text {hitung }}>$ $t_{\text {tabel }}(2,217>1,989)$ dengan taraf signifikansi 5\% dan derajat kebebasan 82 . Hal tersebut berarti bahwa pembelajaran matematika dengan pendekatan PMRI banyak memberikan kesempatan kepada siswa untuk melakukan aktivitas belajar secara optimal sehingga dapat berpengaruh pada kompetensi pengetahuan matematika.

Pendekatan PMRI memiliki keunggulan yaitu berorientasi pada penalaran peserta didik yang bersifat realistik sesuai dengan tuntutan kurikulum berbasis kompetensi yang ditunjukkan pada pengembangan pola pikir praktis, logis, kritis serta jujur dengan beorientasi pada penalaran matematika dalam menyelesaikan masalah. Pembelajaran matematika dengan menggunakan pendekatan PMRI merupakan pendekatan yang berorientasi pada siswa dan dalam pembelajarannya dihubungkan secara konkret terhadap konteks kehidupan sehari-hari siswa ke pengalaman belajar yang berorientasi pada halhal yang real (nyata). Pada penelitian ini pendekatan PMRI dalam pembelajaran matematika dapat membuat siswa antusias dan termotivasi dalam pembelajaran karena siswa dalam pembelajaran diberi kesempatan memecahkan masalah yang sering ditemukan di kehidupan nyata (Yulia \& Jamaliah, 2016). Selain itu pendekatan PMRI melatih kreativitas siswa dalam menyelesaikan masalah matematika dengan menggunakan berbagai cara namun masih sesuai dengan langkah-langkah PMRI (Amelia \& Isrok'atun 2018). Maka dari itu siswa harus memiliki kesiapan, keberanian serta keinginan yang kuat untuk mampu 
menyampaikannya di depan kelas. Keterlibatan yang aktif dengan gagasan-gagasan tersebut mendorong aktivitas siswa untuk berpikir, menemukan, menganalisis, serta menyimpulkan pemahaman konsep yang kemudian mengintegrasikan dengan konsep yang telah mereka miliki sebelumnya sehingga proses belajar-mengajar lebih bermakna serta lebih menggembirakan sesuai dengan pendapat Putri (2011). Selain itu pendekatan PMRI juga memberi kesempatan kepada siswa untuk saling bekerja sama dalam memecahkan suatu masalah dalam pembelajaran, siswa menjadi lebih bertanggung jawab dengan tugasnya masing-masing, dan siswa pun mendapat kesempatan untuk saling bertukar pikiran dengan temannya. Hal ini sesuai dengan karakteristik PMRI dari (Sembiring, 2010) yang menegaskan bahwa karakteristik dari pendekatan PMRI tersebut adalah: (1) siswa lebih aktif berpikir, (2) konteks dan bahan ajar terkait langsung dengan lingkungan sekolah dan siswa, serta (3) peran guru lebih aktif dalam merancang bahan ajar. Sependapat dengan hal tersebut (Oftiana \& Saefudin, 2017) menjelaskan bahwa PMRI juga merupakan salah satu pendekatan pembelajaran yang inovatif dan memiliki beberapa karakteristik diantaranya yaitu, memberikan kondisi belajar aktif kepada siswa, melibatkan siswa untuk memecahkan suatu masalah dengan cara masing-masing, sehingga siswa dapat mempelajari pengetahuan yang berhubungan dengan masalah tersebut dan sekaligus memiliki keterampilan untuk memecahkan masalah.

Penelitian ini sejalan dengan Nugraheni \& Sugiman (2013) menunjukkan bahwa pendekatan PMRI memberikan pengaruh terhadap aktivitas dan pemahaman konsep matematika. Pendekatan PMRI memberikan hasil yang lebih baik dibandingkan direct instruction ditinjau dari aktivitas dan pemahaman konsep matematika siswa kelas VII SMP Negeri 4 Banguntapan Bantul pada pembelajaran garis dan sudut. Penelitian ini juga sejalan dengan penelitian Muchlis (2012) yang berjudul Pengaruh Pendekatan Pendidikan Matematika Realistik Indonesia (PMRI) Terhadap Perkembangan Kemampuan Pemecahan Masalah Siswa Kelas II SD Kartika 1.10 Padang bahwa hasil penelitiannya menunjukkan kemampuan pemecahan masalah matematika siswa yang belajar dengan pendekatan PMRI lebih baik secara signifikan dari pada siswa yang belajar dengan pendekatan konvensional. Perkembangan kemampuan pemecahan masalah matematika dapat dilihat dari: a) Siswa sudah tidak langsung mengoperasikan angka-angka yang ada, tetapi siswa memaknai terlebih dahulu maksud dari soal kemudian baru menentukan pendekatan atau cara yang tepat digunakan untuk menyelesaikan permasalahan tersebut. b) Siswa sudah mampu menyelesaikan soal secara prosedural. Terlihat dengan variasi cara yang digunakan siswa dalam menyelesaikan permasalahan yang diberikan. Hasil penelitian ini sesuai dengan hasil penelitian Putri (2011) yang berjudul Pembelajaran Materi Bangun Datar melalui Cerita menggunakan Pendekatan Pendidikan Matematika Realistik Indonesia (PMRI) di Sekolah Dasar bahwa siswa aktif mengikuti pembelajaran menggunakan tangram yang dilihat dari prinsip dan karakteristik PMRI. Hal ini disebabkan karena konteks berburu yang digunakan menarik dan nyata bagi siswa serta proses pembelajaran sangat interaktif.

Pembelajaran matematika melalui pendekatan PMRI memiliki efektivitas dengan kategori efek sedang. Hal tersebut dapat terjadi karena di luar model pembelajaran yang diterapkan terdapat faktorfaktor lain yang juga berpengaruh terhadap kompetensi pengetahuan matematika siswa. Faktor tersebut yaitu kategori efektivitas sedang disebabkan oleh pembelajaran matematika menggunakan PMRI baru diterapkan pada saat penelitian berlangsung. Untuk memperoleh efektivitas dengan katagori besar dibutuhkan pembiasaan pembelajaran matematika dengan menggunakan pendekatan PMRI. Berdasarkan pemaparan tersebut, dapat dikatakan bahwa pembelajaran matematika melalui pendekatan PMRI berpengaruh terhadap kompetensi pengetahuan matematika kelas IV SD Gugus Kompyang Sujana tahun ajaran 2019/2020, serta memiliki efek sedang.

Implikasi dalam penelitian ini adalah pendekatan PMRI merupakan salah satu alternatif pembelajaran yang dapat digunakan guru untuk diterapkan di kelas IV terutama dalam proses pembelajaran sebagai upaya mengoptimalkan kompetensi pengetahuan matematika siswa. Pendekatan ini memberikan peluang terhadap peserta didik untuk aktif dan termotivasi saat mengemukakan ide atau gagasannya serta siswa dapat memahami materi, karena siswa dalam pembelajaran diberikan kesempatan memecahkan masalah yang sering ditemukan dikehidupan nyata dan pembelajaran selalu dikaitkan dengan kehidupan sehari-hari mereka. Berdasarkan hasil pengamatan, pendekatan PMRI cocok digunakan dalam proses pembelajaran matematika dilihat dari hasil nilai kompetensi pengetahuan matematika siswa yaitu terdapat perbedaan nilai kompetensi matematika yang dibelajarkan dengan menggunakan pendekatan PMRI dengan nilai kompetensi matematika yang dibelajarkan dengan pembelajaran konvensional. Pendekatan PMRI juga terbukti dapat meningkatkan minat siswa terutama dalam proses pembelajaran matematika untuk menjadikan siswa lebih kreatif dan inovatif sesuai dengan kebijakan dan kurikulum 2013. 


\section{KESIMPULAN}

Berdasarkan hasil analisis dapat disimpulkan terdapat perbedaan yang signifikan kompetensi pengetahuan matematika kelompok yang dibelajarkan dengan pendekatan PMRI dengan kelompok yang dibelajarkan melalui pembelajaran konvensional pada kelas IV SD Kompyang Sujana tahun ajaran 2019/2020 dan diperoleh efektivitas dengan kategori efek sedang. Adapun beberapa hasil penelitian ini, maka rekomendasi yang dapat diajukan adalah kepada guru, melihat hasil penelitian pada kompetensi pengetahuan matematika dengan pendekatan PMRI, hendaknya guru menerapkan dengan pendekatan PMRI pada kompetensi pengetahuan matematika. Kepada Kepala Sekolah, hendaknya menyediakan sarana yang maksimal untuk menunjang pelajaran agar siswa semakin termotivasi untuk belajar dan memanfaat sarana tersebut untuk mengoptimalkan hasil belajar siswa sehingga mutu sekolah menjadi semakin meningkat. Kepada Peneliti Lain, dengan dilakukannya penelitian ini, diharapkan peneliti lain melakukan penelitian lebih lanjut dengan menerapkan pendekatan pembelajaran matematika melalui pendekatan PMRI pada sumber data/sampel yang berbeda khususnya pada kompetensi pengetahuan matematika sehingga hasil penelitian benar-benar dapat menggambarkan keadaan sesungguhnya yang terjadi di lapangan.

\section{DAFTAR PUSTAKA}

Advina Ria Christianti, M., Wiarta, I. W., \& Oka Negara, I. G. (2018). Pengaruh Model Pembelajaran Discovery Learning Berbasis Penilaian Portofolio Terhadap Kompetensi Pengetahuan Matematika Siswa Kelas Iv. Mimbar Ilmu, 23(1), 86-93.

Amelia, \& Isrok'atun. (2018). Model-Model Pembelajaran Matematika. Pt Bumi Aksara.

Arianti, N., Wiarta, I. W., \& Darsana, I. W. (2019). Pengaruh Model Pembelajaran Problem Posing Berbantuan Media Semi Konkret Terhadap Kompetensi Pengetahuan Matematika. 3(4), 394-402.

Darmayanti, N. P. ., Wiarta, I. W., \& Sastra Agustika, G. N. (2016). Pengaruh Model Pembelajaran Stad Berbasis Portofolio Terhadap Kompetensi Pengetahuan Matematika. E-Journal Pgsd Universitas Pendidikan Ganesha, 4(1), 1-10.

Deviana Novita, N. L., Wiarta, I. W., \& Wiyasa, K. N. (2017). Model Pembelajaran Kooperatif Tipe Scramble Berbantuan Bahan Manipulatif Berpengaruh Terhadap Kompetensi Pengetahuan Matematika. 1, 133140.

Faot, M. M., \& Amin, S. M. (2016). Pengaruh Pendekatan Pendidikan Matematika Realistik Indonesia (PMRI) Terhadap Hasil Belajar Siswa. Jurnal Ilmiah Pendidikan Matematika, 1(5), 59-66.

Hadi, S. (2018). Pendidikan Matematika Realistik. Pt Rajagrafindo Persada.

Ibda, F. (2015). Perkembangan Kognitif: Teori Jean Piaget. Intelektualita, 3(1), 242904.

Idris, \& Silalahi, K. (2016). Penerapan Pendekatan Pendidikan Matematika Realistik (Pmr) Untuk Meningkatkan Kemampuan Penyelesaian Soal Cerita. Jurnal Edumatsains, 1(1), 73-82.

J.W., S. (2008). Psikologi Pendidikan (Terjemahan). Kencana.

Kusmanto, H., \& Marliyana, I. (2014). Pengaruh Pemahaman Matematika Terhadap Kemampuan Koneksi Matematika Siswa Kelas Vii Semester Genap SMP Negeri 2 Kasokandel Kabupaten Majalengka. Eduma : Mathematics Education Learning And Teaching, 3(2).

Lus, E., Palupi, W., Khabibah, S., Lukito, A., \& Amin, S. M. (2020). Dengan Media Berbahan Bekas Di Sekolah Dasar. 5(2), 97-105.

Muchlis, E. (2012). Pengaruh Pendekatan Pendidikan Matematika Realistik Indonesia (PMRI) Terhadap 
Perkembangan Kemampuan Pemecahan Masalah Siswa Kelas Ii Sd Kartika 1.10 Padang. Exacta, 10(2), 136-139.

Munir, M., \& Shoelahah, H. (2020). Pembelajaran Matematika Realistik Indonesia (PMRI) Dalam Meningkatkan Kemampuan Pemecahan Masalah. Jurnal Al-Muta'aliyah Darul Kamang Nw Kemang Kerang, 5(1).

Novita, R. (2015). Korelasi Kemampuan Pemecahan Masalah Matematis Terhadap Prestasi Belajar Siswa SMP Negeri 4 Banda Aceh. Jurnal Pendidikan Matematika, 2(1), 86-96.

Novitasari, D. (2016). Pengaruh Penggunaan Multimedia Interaktif Terhadap Kemampuan Pemahaman Konsep Matematis Siswa. Fibonacci: Jurnal Pendidikan Matematika Dan Matematika, 2(2), 8.

Novitasari, L., \& Leonard. (2017). Pengaruh Kemampuan Awal Terhadap Hasil Belajar Matematika. Jkpm (Jurnal Kajian Pendidikan Matematika), 2(1), 37.

Nugraheni, E. A. (2013). Pengaruh Pendekatan PMRI Terhadap Aktivitas Dan Pemahaman Konsep Matematika Siswa SMP. Pengaruh Pendekatan PMRI Terhadap Aktivitas Dan Pemahaman Konsep Matematika Siswa SMP, 8(1), 101-108.

Oftiana, S., \& Saefudin, A. A. (2017). Pengaruh Pendekatan Pembelajaran Matematika Realistik Indonesia (PMRI) Terhadap Kemampuan Pemecahan Masalah Matematika Siswa Kelas Vii SMP Negeri 2 Srandakan. Mapan, 5(2), 293-301.

Pratiwi, I. (2019). Efek Program PISA Terhadap Kurikulum Di Indonesia. Jurnal Pendidikan Dan Kebudayaan, 4(1).

Prihartini, N., Sari, P., \& Hadi, I. (2020). Design Research : Mengembangkan Pembelajaran Konsep Peluang Dengan Pendekatan Pendidikan Matematika Realistik Indonesia Pada Siswa Kelas IX Di SMPN 220 Jakarta. 4(8), 1-8.

Putri, R. I. I. (2011). Pembelajaran Materi Bangun Datar Melalui Cerita Menggunakan Pendekatan Pendidikan Matematika Realistik Indonesia (PMRI) Di Sekolah Dasar. Jurnal Pendidikan Dan Pembelajaran, 18(2).

Saleh, M., Charitas, R., Prahmana, I., \& Isa, M. (2018). Improving The Reasoning Ability Of Elementary School Student Through The Indonesian Realistic. Journal On Mathematics Education, 9(1), 41-54.

Sembiring, K. R. (2010). Pendidikan Matematika Realistik Indonesia (PMRI). Indoms. J.M.E, 1(1).

Setiawan, A. (2016). Hubungan Kausal Penalaran Matematis Terhadap Prestasi Belajar Matematika Pada Materi Bangun Ruang Sisi Datar Ditinjau Dari Motivasi Belajar Matematika Siswa. Jurnal Pendidikan Matematika, 7(1), 91-100.

Setyaningsih, H., Wardono, \& Prabowo, A. (2017). The Effectiveness Of PMRI Approach Aided By Educational Props To Improve Student's Mathematical Literacy. Unnes Journal Of Mathematics Education, 6(1), 44-51.

Wahidin, \& Sugiman. (2014). Pengaruh Pendekatan PMRI Terhadap Motivasi Berprestasi, Kemampuan Pemecahan The Effect Of The Irme Approach On The Achievement Motivation , Problem Solving Skills , And Learning Achievement. Pythagoras, 9, 99-109.

Wibowo, A. (2017). Pengaruh Pendekatan Pembelajaran Matematika Realistik Dan Saintifik Terhadap Prestasi Belajar, Kemampuan Penalaran Matematis Dan Minat Belajar. Jurnal Riset Pendidikan Matematika, 4(1), 1.

Widodo, M. S. (2014). Keefektifan Pembelajaran Matematika Dengan Pendekatan Pendidikan Matematika Realistik Indonesia (PMRI) Pada Materi Lingkaran Di Kelas Viii SMP. Jurnal Ilmiah Pendidikan Matematika, 3(2), 42-48. 
Widyastuti, N. S., \& Pujiastuti, P. (2014). Pengaruh Pendidikan Matematika Realistik Indonesia (PMRI) Terhadap Pemahaman Konsep Dan Berpikir Logis Siswa. Jurnal Prima Edukasia, 2(2).

Yulia, \& Jamaliah. (2016). Efektivitas Pembelajaran Matematika Melalui PMRI Terhadap Hasil Belajar Siswa Kelas Viii. Pythagoras : Jurnal Program Studi Pendidikan Matematika, 5(2). 